\title{
- \\ Dissolution of Zinc Oxide Nanoparticles in the Presence of Slow Acid Generators
}

\author{
Ronny Kürsteiner, Maximilian Ritter (D), Yong Ding (D) and Guido Panzarasa *
}

Citation: Kürsteiner, R.; Ritter, M.; Ding, Y.; Panzarasa, G. Dissolution of Zinc Oxide Nanoparticles in the Presence of Slow Acid Generators. Materials 2022, 15, 1166. https:// doi.org/10.3390/ma15031166

Academic Editor: Alina Pruna

Received: 11 January 2022

Accepted: 30 January 2022

Published: 2 February 2022

Publisher's Note: MDPI stays neutral with regard to jurisdictional claims in published maps and institutional affiliations.

Copyright: (C) 2022 by the authors. Licensee MDPI, Basel, Switzerland. This article is an open access article distributed under the terms and conditions of the Creative Commons Attribution (CC BY) license (https:// creativecommons.org/licenses/by/ $4.0 /)$.
Wood Materials Science, Institute for Building Materials, ETH Zürich, Laura-Hezner-Weg 7, 8093 Zürich, Switzerland; ronnyk@ethz.ch (R.K.); maxritter@ethz.ch (M.R.); yoding@ethz.ch (Y.D.)

* Correspondence: guidop@ethz.ch

\begin{abstract}
We describe a preliminary investigation of the dissolution dynamics of zinc oxide nanoparticles in the presence of cyclic esters ( $\delta$-gluconolactone and propanesultone) as slow acid generators. The particles dissolution is monitored by means of turbidimetry and correlated with the evolution of $\mathrm{pH}$ over time. The results could be of interest for the design of chemically programmable colloidal systems.
\end{abstract}

Keywords: zinc oxide; propanesultone; gluconolactone; slow acid generation; dissolution; nanoparticles; programmable assembly and disassembly; $\mathrm{pH}$

\section{Introduction}

Investigating the dissolution of inorganic nanoparticles is a topic of great relevance, both theoretical and practical, with applications ranging from advanced materials to environmental science and medicine [1-4]. Cyclic esters are slow acid generators, useful for controlling the evolution of $\mathrm{pH}$ in time due to the acids produced by their hydrolysis [5]. As such, they are important tools for the application of systems chemistry principles to materials science [6,7]. In the context of our research on the chemical programming of material systems, we became interested in applying the same principles to inorganic materials, in addition to supramolecular and polymeric ones [8-15]. We began by studying the dissolution dynamics of inorganic nanoparticles in the presence of slow acid generators. For our preliminary investigation, we chose zinc oxide $\mathrm{ZnO}$ nanoparticles as a model system for its great relevance [16-23] and commercial availability. As slow acid generators, we chose a lactone, $\delta$-gluconolactone (GL), and a sultone, 1,3-propanesultone (PrS). The kinetics of hydrolysis of both are already known, and their reaction with water (Equations (1) and (2)) give, respectively, gluconic acid $\left(\mathrm{pK}_{\mathrm{a}} 3.86\right.$, a typical carboxylic acid) [5] and 1-hydroxypropanesulfonic acid ( $\mathrm{pK}_{\mathrm{a}}$ 1.53, a typical sulfonic acid) [10], which are both strong enough to dissolve zinc oxide, thus forming the corresponding soluble salts (Equations (1) and (2)):
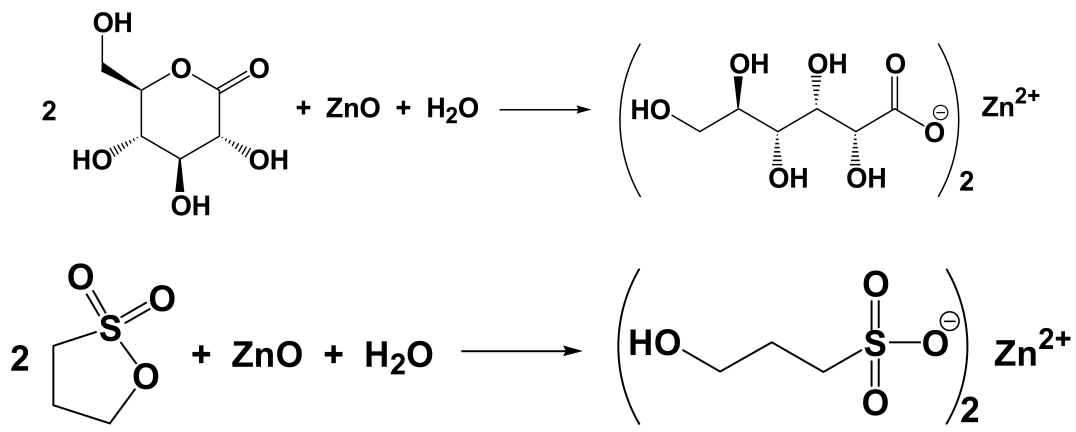
We studied the dissolution of $\mathrm{ZnO}$ nanoparticles by measuring the evolution of $\mathrm{pH}$ and turbidity over time, keeping constant the concentration of $\mathrm{ZnO}(5 \mathrm{mM})$ and varying that of the slow acid generators (50, 100, or $200 \mathrm{mM})$. With a lower (1 mM) ZnO concentration, the dissolution was too fast (especially with GL) to ensure proper turbidimetry measurements.

\section{Materials and Methods}

Zinc oxide dispersion (nanoparticles, $<100 \mathrm{~nm}$ particle size (TEM), $\leq 40 \mathrm{~nm}$ avg. part. Size (APS), 20 wt. $\%$ in $\mathrm{H}_{2} \mathrm{O}$ ), $\delta$-gluconolactone (GL, meets USP testing specifications), and 1,3-propanesultone (PrS, 98\%) were purchased from Sigma-Aldrich, St. Louis, MO, USA. Unless otherwise stated, all chemicals were of an analytical or reagent grade purity and used as received. Water was purified by means of a MilliQ system (resistivity $\geq 18 \mathrm{M} \Omega$ ). All the experiments were performed at room temperature $\left(23 \pm 1^{\circ} \mathrm{C}\right)$.

For pH measurements, a Hanna Instruments (Woonsocket, RI, USA) HI5222-02 benchtop $\mathrm{pH}$-meter was used together with a HI1330B glass body combination $\mathrm{pH}$ microelectrode from the same company. The $\mathrm{pH}$-meter was calibrated with standard buffer solutions $(\mathrm{pH}$ values: $1.68,4.01,7.01,10.01$, and 12.45) before each set of analysis. The $\mathrm{pH}$-electrode was cleaned after each analysis by repeated immersion in water, the excess water gently was removed with hairless paper and immediately immersed in the solution to be analyzed. The $\mathrm{pH}$-meter was interfaced with a computer through the software HI92000-5.0.38 (Hanna Instruments, Woonsocket, RI, USA) to allow continuous recording of $\mathrm{pH}$ values with a time interval of $2 \mathrm{~s}$. The $\mathrm{pH}$ measurements were carried out on a $10-\mathrm{mL}$ reaction mixture, in 15-mL glass vials with stirring of $500 \mathrm{rpm}$.

Turbidimetry measurements were performed with a PerkinElmer (PerkinElmer Life and Analytical Sciences, 710 Bridgeport Avenue Shelton, CT 06484-4794 USA) LAMBDA $650 \mathrm{UV}$-visible spectrophotometer using a quartz cuvette with an optical path of $1 \mathrm{~cm}$. The content of the cuvette was stirred $(500 \mathrm{rpm})$ with a suitable magnetic bar. The measurements were performed at a fixed wavelength $(600 \mathrm{~nm})$ with a 30 -s time interval. For the experiments with PrS, $12 \mu \mathrm{L}$ of the $\mathrm{ZnO}$ dispersion were diluted in a vial with $8 \mathrm{~mL}$ of water. The PrS was dissolved in water (total volume $2 \mathrm{~mL}$ ) by sonication, and added to the $\mathrm{ZnO}$ dispersion. For the experiments with GL, $12 \mu \mathrm{L}$ of the $\mathrm{ZnO}$ dispersion were diluted in a vial with $9 \mathrm{~mL}$ of water. The GL was dissolved in $1 \mathrm{~mL}$ of water by sonication, and added to the $\mathrm{ZnO}$ dispersion. In both cases, the mixture was then transferred to the cuvette under stirring and the measurement started, in any case with a delay $\leq 60 \mathrm{~s}$ from the addition of the slow acid generator (PrS or GL).

Transmission electron microscopy (TEM) was performed with a Jeol JEM 1400 instrument at $120 \mathrm{kV}$ acceleration voltage. To prepare the sample, a drop of dilute particle suspension was deposited on a carbon-coated 400-mesh sized copper grid and air dried.

X-ray powder diffraction (XRPD) was performed with a Panalytical X'Pert PRO MPD using $\mathrm{Cu} \mathrm{K} \alpha 1$ radiation in Bragg-Brentano geometry. The $\mathrm{ZnO}$ suspension was centrifuged and air dried, then the powdered sample was placed on a zero-background sample holder and measured from $5^{\circ}$ to $80^{\circ} 2 \theta$ with a step size of $0.0668^{\circ}$ and a scan speed of $0.034^{\circ} \mathrm{s}^{-1}$ whilst continuously spinning at $15 \mathrm{~min}^{-1}$ and maintaining an X-ray footprint of $10 \times 10 \mathrm{~mm}^{2}$. The crystallite size was estimated using Scherrer's equation [24], assuming a Scherrer formfactor of 1.

Dynamic light scattering (DLS) measurements were performed with a Malvern Zetasizer Nano ZS, employing a non-invasive back scatter detection system at a $173^{\circ}$ detection angle. Prior to measurements, the $\mathrm{ZnO}$ dispersions were diluted by a factor of 20 to mitigate further dissolution and adjust the count rate. The measurements consisted of 10 runs of $10 \mathrm{~s}$ each and were performed in disposable polystyrene cuvettes at $25^{\circ} \mathrm{C}$. The refractive indices of sample and dispersant were set to 1.99 and 1.33, respectively. The viscosity of the dispersant was set to $0.8872 \mathrm{cP}$. 


\section{Results and Discussion}

The commercial $\mathrm{ZnO}$ nanoparticle dispersion was characterized by means of transmission electron microscopy (TEM; Figures $1 \mathrm{a}$ and $\mathrm{S} 1$ ) and X-ray powder diffraction (XRPD, Figure $1 \mathrm{~b}$ ). The results are in good agreement with the data given by the producer. TEM shows relatively polydisperse spheroidal and plate-like particles, with an average crystallite size around $13 \pm 1 \mathrm{~nm}$ (estimated from X-ray diffraction data).

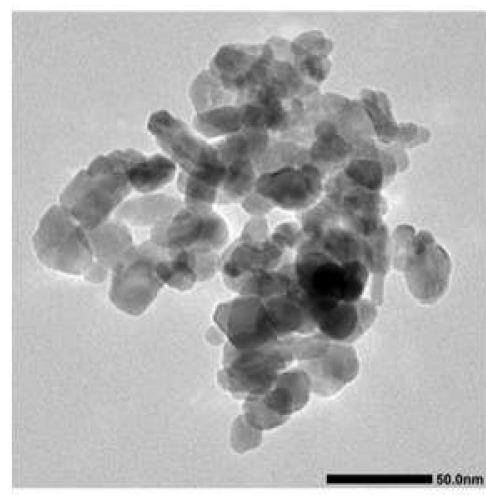

(a)

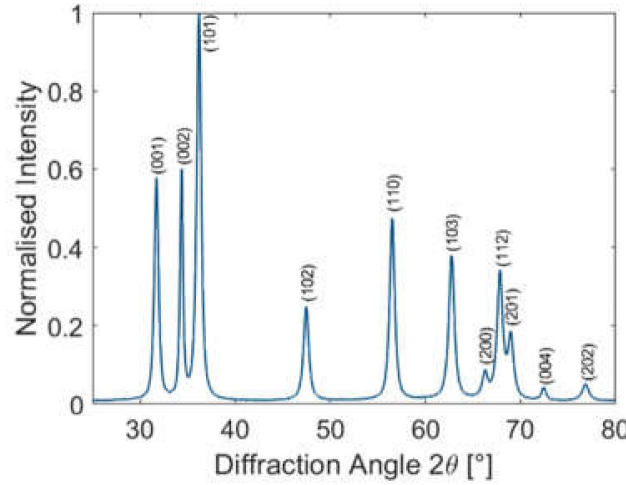

(b)

Figure 1. Representative (a) TEM image (scale bar $50 \mathrm{~nm}$ ) and (b) XRPD pattern of the ZnO nanoparticles used for the experiments.

The hydrolysis of GL is much faster than that of PrS. Nevertheless, in the range of concentrations (50-200 $\mathrm{mM})$ and over the timescales $(<3 \mathrm{~h})$ investigated here, the hydrolysis of both GL and PrS occurs approximately at a constant rate [10]. In the absence of $\mathrm{pH}-$ buffering effects, this results in a steady decrease of $\mathrm{pH}$, as shown in Figure $\mathrm{S} 2$. On the other hand, in presence of $\mathrm{ZnO}$, the $\mathrm{pH}$-time evolution of both $\mathrm{GL}$ and $\mathrm{PrS}$ is characterized by two inflection points (Figure 2, solid lines), which are more evident the higher the concentration of cyclic ester.

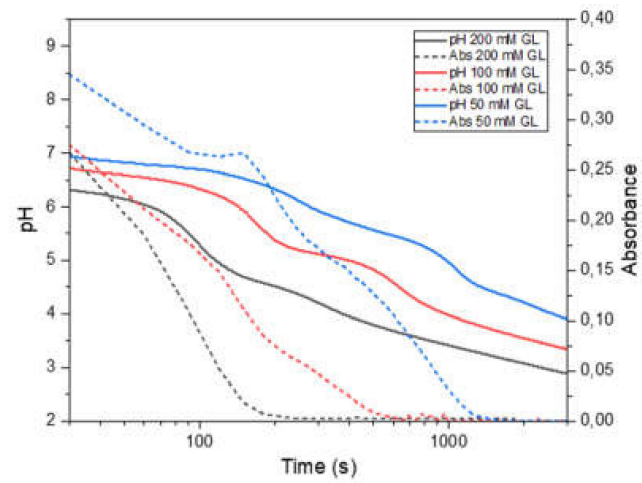

(a)

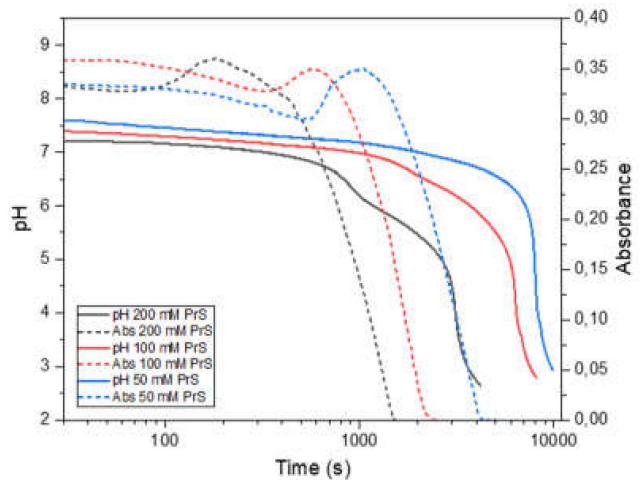

(b)

Figure 2. Evolution of $\mathrm{pH}$ and turbidity over time for a $5 \mathrm{mM} \mathrm{ZnO}$ suspension with different concentrations of slow acid generators: (a) $\delta$-gluconolactone and (b) 1,3-propanesultone.

From the associated turbidimetry plots (Figure 2, dotted lines) it is possible to relate the observed $\mathrm{pH}$ changes with the $\mathrm{ZnO}$ dissolution. In the system $\mathrm{ZnO}-\mathrm{GL}$ (Figure 2a), there is a constant, almost linear decrease in turbidity, with inflection points which follow the trend of those observed in the $\mathrm{pH}$ curves. In the system $\mathrm{ZnO}-\mathrm{PrS}$, by contrast, initially the decrease in turbidity is very slow and is even followed by a transient increase, after which it decreases very rapidly. In addition, in this case there is a good agreement with the temporal evolution of $\mathrm{pH}$, except for these transient increases in turbidity, whose maxima are all in correspondence of a $\mathrm{pH} \approx 7$ for all three PrS concentrations. This increase in turbidity 
could be due to the formation of particle aggregates. Dynamic light scattering (DLS) indeed showed a dramatic increase in the hydrodynamic particle size, however with great delay, which is after the transient increase in turbidity that was observed in the spectrophotometer (Figure S3). This delay could have been due to the different experimental conditions (sample more diluted and unstirred). The mechanism leading to a transient aggregate formation is not yet clear, however it is plausible to hypothesize that the steady acid generation would not only cause particle dissolution but also interfere with their surface charge, thus reducing their electrostatic repulsion. Zeta potential titration has been used to attempt to validate this hypothesis, however the results were not conclusive. Another hypothesis would involve the preferential dissolution of certain crystal planes, facilitating the oriented attachment of the particles.

Although preliminary, these observations allow one to conclude that the dissolution of zinc oxide nanoparticles can be achieved using slow acid generators, and that the dynamics of the process are strongly influenced not only by their concentrations but especially by their nature. More accurate insight will be obtained by repeating these experiments using particles of a controlled size and size distribution, shape, crystallinity, and chemical composition. Measuring the concentration of zinc ions in solution as a function of time, together with the evolution of $\mathrm{pH}$, could help in further understanding the particle dissolution dynamics. Given the versatility of slow acid generators for the programming of pH-controlled colloidal systems, their application to inorganic nanoparticles could provide interesting opportunities.

Supplementary Materials: The following are available online at https:/ / www.mdpi.com/article / 10.3390/ma15031166/s1, Figure S1: Representative TEM images of the ZnO nanoparticles used for the experiments. Figure S2: pH-Time curves for different concentrations of (a) $\delta$-gluconolactone, (b) propanesultone in pure water. Figure S3: DLS curves for the system $\mathrm{ZnO}-\mathrm{PrS}$.

Author Contributions: Conceptualization, G.P.; investigation, R.K., M.R., Y.D. and G.P.; writing—original draft preparation, G.P.; writing-review and editing, G.P.; supervision, G.P.; project administration, G.P.; funding acquisition, G.P. All authors have read and agreed to the published version of the manuscript.

Funding: This research was funded by the ETH Career Seed Grant SEED-12 20-1.

Institutional Review Board Statement: Not applicable.

Informed Consent Statement: Not applicable.

Data Availability Statement: Not applicable.

Acknowledgments: The authors kindly acknowledge the support of Ingo Burgert.

Conflicts of Interest: The authors declare no conflict of interest. The funders had no role in the design of the study; in the collection, analyses, or interpretation of data; in the writing of the manuscript, or in the decision to publish the results.

\section{References}

1. Feliu, N.; Docter, D.; Heine, M.; Del Pino, P.; Ashraf, S.; Kolosnjaj-Tabi, J.; Macchiarini, P.; Nielsen, P.; Alloyeau, D.; Gazeau, F.; et al. In vivo degeneration and the fate of inorganic nanoparticles. Chem. Soc. Rev. 2016, 45, 2440-2457. [CrossRef]

2. Sharma, V.K.; Filip, J.; Zboril, R.; Varma, R.S. Natural inorganic nanoparticles-formation, fate, and toxicity in the environment. Chem. Soc. Rev. 2015, 44, 8410-8423. [CrossRef] [PubMed]

3. Avramescu, M.L.; Rasmussen, P.E.; Chénier, M.; Gardner, H.D. Influence of pH, particle size and crystal form on dissolution behaviour of engineered nanomaterials. Environ. Sci. Pollut. Res. 2017, 24, 1553-1564. [CrossRef] [PubMed]

4. Hedberg, J.; Blomberg, E.; Odnevall Wallinder, I. In the Search for Nanospecific Effects of Dissolution of Metallic Nanoparticles at Freshwater-Like Conditions: A Critical Review. Environ. Sci. Technol. 2019, 53, 4030-4044. [CrossRef] [PubMed]

5. Bánsági, T.; Taylor, A.F. Ester hydrolysis: Conditions for acid autocatalysis and a kinetic switch. Tetrahedron 2017, 73, 5018-5022. [CrossRef]

6. Tóth-Szeles, E.; Horváth, J.; Holló, G.; Szcs, R.; Nakanishi, H.; Lagzi, I. Chemically coded time-programmed self-assembly. Mol. Syst. Des. Eng. 2017, 2, 274-282. [CrossRef] 
7. Van Roekel, H.W.H.; Rosier, B.J.H.M.; Meijer, L.H.H.; Hilbers, P.A.J.; Markvoort, A.J.; Huck, W.T.S.; De Greef, T.F.A. Programmable chemical reaction networks: Emulating regulatory functions in living cells using a bottom-up approach. Chem. Soc. Rev. 2015, 44, 7465-7483. [CrossRef] [PubMed]

8. Panzarasa, G.; Osypova, A.; Sicher, A.; Bruinink, A.; Dufresne, E.R. Controlled formation of chitosan particles by a clock reaction. Soft Matter 2018, 14, 6415-6418. [CrossRef]

9. Panzarasa, G.; Dufresne, E.R. Impact of in situ acid generation and iodine sequestration on the chlorite-iodide clock reaction. Chaos 2019, 29, 071102. [CrossRef]

10. Panzarasa, G.; Sai, T.; Torzynski, A.L.; Smith-Mannschott, K.; Dufresne, E.R. Supramolecular assembly by time-programmed acid autocatalysis. Mol. Syst. Des. Eng. 2020, 5, 445-448. [CrossRef]

11. Panzarasa, G.; Torzynski, A.L.; Sai, T.; Smith-Mannschott, K.; Dufresne, E.R. Transient supramolecular assembly of a functional perylene diimide controlled by a programmable $\mathrm{pH}$ cycle. Soft Matter 2020, 16, 591-594. [CrossRef] [PubMed]

12. Riedel, S.; Schweizer, T.; Smith-Mannschott, K.; Dufresne, E.R.; Panzarasa, G. Supramolecular gelation controlled by an iodine clock. Soft Matter 2021, 17, 1189-1193. [CrossRef] [PubMed]

13. Riedel, S.; Panzarasa, G. Stable and transient self-propagating supramolecular gelation. Mol. Syst. Des. Eng. 2021, 6, 883-887. [CrossRef]

14. Panzarasa, G.; Dufresne, E.R. Temporal Control of Soft Materials with Chemical Clocks. Chimia 2020, 74, 612. [CrossRef]

15. Sproncken, C.C.M.; Gumi-Audenis, B.; Panzarasa, G.; Voets, I.K. Two-Stage Polyelectrolyte Assembly Orchestrated by a Clock Reaction. ChemSystemsChem 2020, 2, e2000005. [CrossRef]

16. Gerischer, H.; Liibke, M.; Sorg, N. A Study of the Chemical Dissolution of Semiconductors in Aqueous Electrolytes with Zinc Oxide as Example. Z. Phys. Chemie 1986, 148, 11-19. [CrossRef]

17. Cardoso, D.; Narcy, A.; Durosoy, S.; Bordes, C.; Chevalier, Y. Dissolution kinetics of zinc oxide and its relationship with physicochemical characteristics. Powder Technol. 2021, 378, 746-759. [CrossRef]

18. Tan, Z.; Chen, Q.; Yin, Y.; Liu, Y.; Lin, Y.; Bai, Q.; Wu, M.; Yao, W.; Xu, S.; Liu, J. Tracking the dissolution behavior of zinc oxide nanoparticles in skimmed milk powder solutions. Food Chem. 2021, 365, 130520. [CrossRef]

19. Eixenberger, J.E.; Anders, C.B.; Hermann, R.J.; Brown, R.J.; Reddy, K.M.; Punnoose, A.; Wingett, D.G. Rapid Dissolution of ZnO Nanoparticles Induced by Biological Buffers Significantly Impacts Cytotoxicity. Chem. Res. Toxicol. 2017, 30, 1641-1651. [CrossRef]

20. Jiang, C.; Aiken, G.R.; Hsu-Kim, H. Effects of Natural Organic Matter Properties on the Dissolution Kinetics of Zinc Oxide Nanoparticles. Environ. Sci. Technol. 2015, 49, 11476-11484. [CrossRef]

21. Anders, C.B.; Eixenberger, J.E.; Franco, N.A.; Hermann, R.J.; Rainey, K.D.; Chess, J.J.; Punnoose, A.; Wingett, D.G. ZnO nanoparticle preparation route influences surface reactivity, dissolution and cytotoxicity. Environ. Sci. Nano 2018, 5, 572. [CrossRef] [PubMed]

22. Elhaj Baddar, Z.; Matocha, C.J.; Unrine, J.M. Surface coating effects on the sorption and dissolution of ZnO nanoparticles in soil Environ. Sci. Nano 2019, 6, 2495. [CrossRef]

23. Leung, C.Y.; Tu, Y.; Tang, B.Z.; Wang, W.X. Dissolution kinetics of zinc oxide nanoparticles: Real-time monitoring using a Zn2+-specific fluorescent probe. Environ. Sci. Nano 2019, 6, 2259. [CrossRef]

24. Scherrer, P. Bestimmung der inneren Struktur und der Größe von Kolloidteilchen mittels Röntgenstrahlen. In Kolloidchemie Ein Lehrbuch. Chemische Technologie in Einzeldarstellungen; Springer: Berlin/Heidelberg, Germany, 1912. [CrossRef] 